\title{
Environmental, social and structural aspects involving the expansion of macro photovoltaic energy in Brazil
}

\author{
C. F. Freire \& G. A. Trevisan \\ Grupo Energia, Brazil
}

\begin{abstract}
Reasons such as environmental appeal and work costs made photovoltaic energy attractive to investors in Brazil, a country that has both public and private energy production. In Brazil, the best region in solar radiation is the caatinga biome, which is the least environmentally protected biome in the country. It has a low and poor population with few civil organizations and a precarious infrastructure. Aiming for sustainable development for the area, some issues on conservation and the environmentally fragile status, the great future infrastructure projects, the presence of transmission lines, major urban centers and supply access were investigated. This analysis leads to conclusions in that the implementation of solar farms can be very positive for the development of the area, but fragile points and risks must be considered. The few quantities of protected areas, endemic and endangered species in the region, a vague and ambiguous environmental law framework, delays in the construction of major infrastructure projects and lack of transmission lines in some regions represent risks for a well done and sustainable installation of the solar plans. To maximize the positive mpacts that these farms could bring, it is necessary to create new protected areas and have a well-defined environmental law framework established by the federal government, as well as a previous engagement by the parts involved.
\end{abstract}

Keywords: photovoltaic energy, Brazilian caatinga, conservation units, sustainable development, environmental licenses.

\section{Introduction}

The use of solar energy as electrical energy is still low in Brazil, being used only in restricted, local areas, mainly in private houses or industries, but the recent 
development of solar panels bringing it to a lower cost, turned the production of this energy to be viable as a part of the country energetic matrix. Despite the originality of the issue, it has been interesting to investors, due to characteristics such as environmental appeal, low handwork and work costs and others facilities for implementation [1].

On the other side, it is known that land exploitation without planning, especially in areas with low occupation, can be dangerous, bringing environmental and social problems and impacts, which cost more than the expected development [2]. Previous experience on implementation projects of renewable energy led to negative social and environmental consequences, showing that previous planning is essential before carrying these projects in large scale [3].

Small hydroelectric and eolic plans were very welcome because of their low environmental and social impacts, but as time has passed, problems linked to the absence of planning came abroad, like changing people from their original properties, impacts on fish populations, visual impact, interference on birds and many others, depending on the size and place of these plans. As these incidents occur, license procedures get difficult and social empathy decreases.

So, the analyses presented here aim at pointing negative and positive impacts which can occur in the implementation of solar farms in Brazilian caatinga, hoping to contribute for the improvement of the positive impacts for all the agents involved.

\section{Methods}

Information on the regions and the best areas for solar energy exploitation, obtained from both "Atlas Solar Brasileiro" [4] and our own data over measuring stations, gave us the best insolation areas. More geographical information was obtained by overlapping this map of solar radiation with conservation units and priority areas for conservation, major urban centers, regional structural projects and transmission lines. Environmental licensing procedures were also analyzed.

Maps were done in the ArcGIS 10.1 program to illustrate the overlapping of the areas and also to localize urban centers and infrastructure, so visualization of areas becomes easier to be identified. Biological components and abiotic elements, important in each of the priority areas and conservation unit, were listed on a table, so that the most fragile element or component could be identified.

\section{Results}

The best area for solar farms implementation is the so called biome caatinga, which is located in the Northeast Region of Brazil and correspond to $11 \%$ of the total Brazilian territory [5]. This biome has a low occupancy density and it has a large amount of land to be used for this destination. 


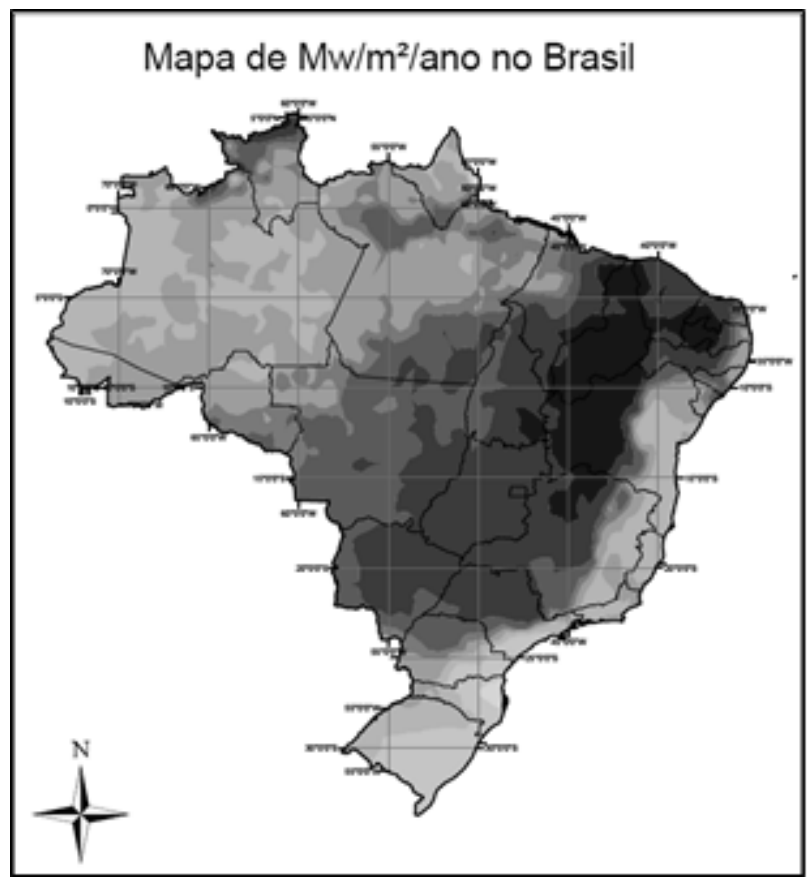

Figure 1: Localization of the areas with the best solar radiation in Brazil.

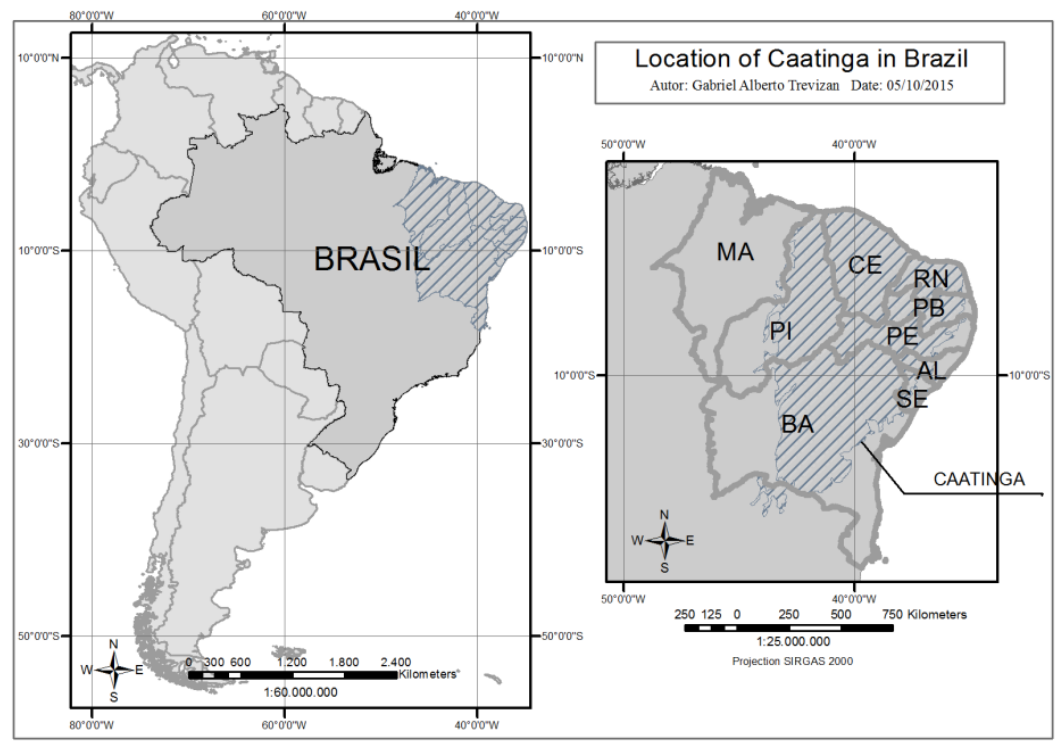

Figure 2: Localization of the caatinga biome in Brazil. 


\subsection{Conservation units and priority areas for conservation in caatinga}

The caatinga biome is the least protected biome in Brazil, considering the amount of conservation units and protected land [5]. The total amount of land protected by conservation units is $4,091,046$ ha, which is very few in comparison to the biome total amount [6]. Despite the effort to increase this number, it remains low.

Federal government has counted on the effort of the states to increase the number of protected areas, but it takes time and the process of creation of these areas is long and has a high cost with expropriations [5].

The few number of conservation units increases priority areas targeted for conservation, as a compensation. We have listed the conservation units and show them as a map figure, so that it is easier to visualize their size and location. The areas of conservation interest are also shown as a map [6] and listed in a table containing the main susceptible biological component, which is the main reason for the area to be preserved. Reasons for the component listed to be important are endemic and/or endangered species, not well known or low understood area or even any other relevant status, as any ecological fragility.

Table 1: Conservation units in caatinga biome.

\begin{tabular}{|l|c|}
\hline Units & Area (ha) \\
\hline Esec de Aiuaba & 11,525 \\
\hline Esec do Castanhão & 12,579 \\
\hline Esec do Seridó & 28,700 \\
\hline Esec Raso da Catarina & 99,772 \\
\hline Rebio de Serra Negra & 1,100 \\
\hline Parna da Chapada Diamantina & 152,000 \\
\hline Parna da Furna Feia & 8,494 \\
\hline Parna da Serra da Capivara & 100,000 \\
\hline Parna da Serra das Confusões & 823,436 \\
\hline Parna de Sete Cidades & 7,700 \\
\hline Parna de Ubajara & 6,288 \\
\hline Parna do Catimbau & 62,555 \\
\hline Mona do Rio São Francisco & 26,715 \\
\hline APA da Chapada do Araripe & $1,063,000$ \\
\hline APA Serra da Ibiapaba & $1,625,019$ \\
\hline APA Serra da Meruoca & 608 \\
\hline Arie Cocorobó & 7,473 \\
\hline Arie Vale dos Dinossauros & 146 \\
\hline Flona Araripe-Apodi & 38,919 \\
\hline Flona Contendas do Sincorá & 11,034 \\
\hline Flona de Açu & 215 \\
\hline Flona de Negreiros & 3,000 \\
\hline Flona de Palmares & 170 \\
\hline Flona de Sobral & 598 \\
\hline Total & $4,091,046$ \\
\hline
\end{tabular}


Table 2: Areas of conservation interest in biome caatinga, by state.

\begin{tabular}{|c|c|}
\hline Area & Biocomponent \\
\hline \multicolumn{2}{|c|}{ State of Bahia } \\
\hline Serra do Curral Feio & Flora \\
\hline Sertão do Submédio São Francisco & Flora \\
\hline São Francisco dunes & Flora \\
\hline Serra do Açuruá & Flora \\
\hline Senhor do Bonfim region & Flora \\
\hline Chapada Diamantina region & Flora \\
\hline Serras de Ipirá e Oboró & Flora \\
\hline Milagres region & Flora \\
\hline Carste do Irecêregion & Flora \\
\hline Bom Jesus da Lapa region & Flora \\
\hline Mares de areia & Invertebrates \\
\hline Xique-xique dunes field & Amphibians/reptiles \\
\hline Santo Inácio dunes field & Amphibians/reptiles \\
\hline Dunas e Casanova & Amphibians/reptiles \\
\hline Curaçá region & Birds \\
\hline Senhor do Bonfim & Birds \\
\hline Morpará & Birds \\
\hline FLONA Araripe surrounds & Birds \\
\hline Bom Jesus da Lapa & Birds \\
\hline Morro do Chapéu & Mammals \\
\hline Médio São Francisco & Mammals \\
\hline Ibipeba region & Mammals \\
\hline Bom Jesus da Lapa surrounds & Mammals \\
\hline \multicolumn{2}{|c|}{ State of Ceará } \\
\hline Serra das Flores & Flora \\
\hline Carnaubais & Flora \\
\hline Serra das Almas & Amphibians/reptiles \\
\hline Quixadá & Amphibians/reptiles \\
\hline Serra do Baturité & Amphibians/reptiles \\
\hline Limoeiro do Norte & Amphibians/reptiles \\
\hline Chapada de Ibiapaba & Amphibians/reptiles \\
\hline Ubajara & Birds \\
\hline Jaburuna region & Flora \\
\hline Angical & Flora \\
\hline Sertão dos Inhamuns & Flora \\
\hline Crato region & Mammals \\
\hline Chapada de Ibiapaba & Mammals \\
\hline Serra de Baturité basin & Mammals \\
\hline Central region of the state & Mammals \\
\hline \multicolumn{2}{|c|}{ State of Minas Gerais } \\
\hline Peruaçu & Birds \\
\hline Jaíba & Birds \\
\hline North of the state & Mammals \\
\hline Porteirinha/Espinosa region & Mammals \\
\hline
\end{tabular}


Table 2: Continued.

\begin{tabular}{|c|c|}
\hline Area & Biocomponent \\
\hline \multicolumn{2}{|c|}{ State of Paraiba } \\
\hline Cariri Paraibano & Flora \\
\hline Rio do Peixe valley & Flora \\
\hline Serra de Santa Catarina & Flora \\
\hline Monte Horebe & Flora \\
\hline Paus Brancos & Flora \\
\hline \multicolumn{2}{|c|}{ State of Pernambuco } \\
\hline Southeast of the state & Flora \\
\hline Sertão do Submédio São Francisco & Flora \\
\hline Serra Talhada & Flora \\
\hline Mirandiba & Flora \\
\hline \multicolumn{2}{|c|}{ State of Piauí } \\
\hline Capivara - Confusões ecological corridor & Flora \\
\hline Capivara - Confusões ecological corridor & Invertebrates \\
\hline Capivara - Confusões ecological corridor & Amphibians/reptiles \\
\hline Capivara - Confusões ecological corridor & Mammals \\
\hline Oeiras & Invertebrates \\
\hline Canto do Buriti & Invertebrates \\
\hline Casanova & Invertebrates \\
\hline Valença & Mammals \\
\hline Babaçual & Mammals \\
\hline Picos & Flora \\
\hline
\end{tabular}

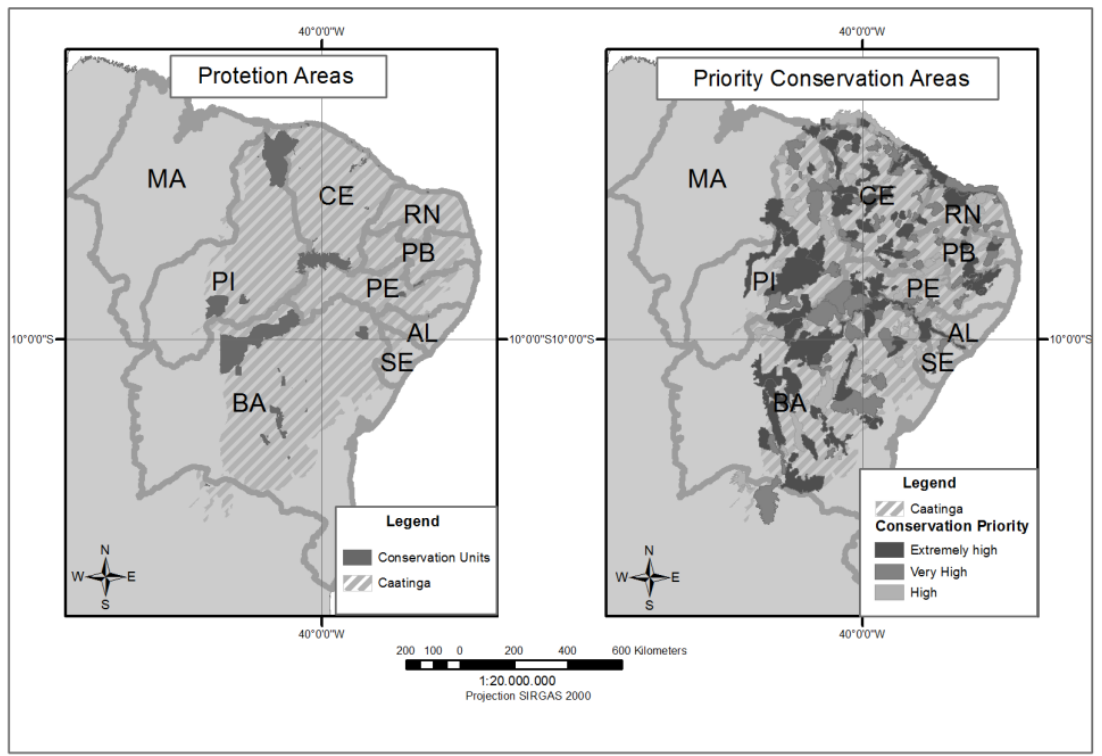

Figure 3: Officially established conservation units and areas considered a priority for conservation purpose in caatinga biome. 
Despite the great quantity of areas which are of major interest for conservation, some are definitely to be observed in accuracy. The arqueological and ecological corridor Serra das Confusões - Serra da Capivara is the most important region to be preserved in the area [7] by the biological view, due to the fact that it is important for all biological components [8]. The region, besides having many important biological components living inside their limits is a world famous arqueological site, with findings dating from 50,000 years ago.

The region called Submédio São Francisco River is very important as well, especially because it is a resting and feeding site for migration birds and also by many flora endemic components [8]. Besides that, the São Francisco River is a real important water supply for the entire region, not just for drinking water, but also for agriculture irrigation, being this region the most important fruit export in the entire country.

The South, Central and West of Ceará state are very important areas too, by many biological components [7]. This site has a mountain range which gives the region a distinguishing overview and ecological feature.

The State of Bahia has its importance especially due to its size. The state has many ecological "hot spots" and singular sites that are important and should be preserved as conservation units. Besides that, the State holds many of the 60 species of fauna which are endangered, and had inside its limits the Ararinhaazul, the emblematic psittaciforme recently extinct in nature.

\subsection{Urban centers}

Urban centers are important as access to general supplies, from labor work from construction inputs, to intellectual consulting. Most major cities and capitals in the Northeast of Brazil are close to the coast, but new centers are rising in the central part of the country.

The city in distinction in this part of the caatinga biome is Juazeiro do Norte, in Ceará State, which is already a reference region and can be the "Capital do Sertão", which means something like the Capital of the arid inland [9].

Another important city in this contest is Petrolina. Nowadays this city is already an important supplier [9], but this can be extremely extended in a near future. Both cities have airports and reasonable routes linking them to most cities in the semiarid region.

\subsection{Major development projects}

Major development projects are supposed to establish new routes and lines for development. The size of Brazil and its political configuration, as a Federation, ends up to the federal government planning large and great projects for integration. A proof of this is the existence of a Ministry of National Integration which is responsible for developing projects which involve several States.

Projects that are being developed in the region were here analyzed [10]. São Francisco River Integration, a symbolic project of water transposition, is here commented. The project has a total of $713 \mathrm{~km}$ of canals, aqueducts, dams, tunnels and pumping stations to divert a small portion of the waters of the São 
Francisco River. The redirected water flow will supply rivers that dry out during the long dry season in the extreme Northeast, an area known as the "drought polygon" [10].

The project is supposed to change some regions in the arid part of northeast Brazil, and the state of Ceará will be the one most modified in its East part. The state of Rio Grande do Norte will also be much granted. The idea is that with water supply many activities can be established in the region, mainly industrial and agricultural activities. Besides water, of course energy is one of the essential supplies needed to this pretension.

Another major project to be distinguished is the railway which will cross the region from East to West, passing through the center of the arid region. This railway has the pretension of bringing products from the arid region to the harbor of Suape [10]. Completed, it can transport lots of products and can impulse the development of the region.

It is expected that with water supply and a low cost transportation, the region will be attractive to industries in general, and that can change the long history of poverty in the caatinga region.

The region is being a new frontier for large scale agriculture nowadays, but there hasn't been a general agreement if that could bring positive impacts to the region, as it brings good trade balance to the country, but it seems to be unable to develop socially and economically locally.

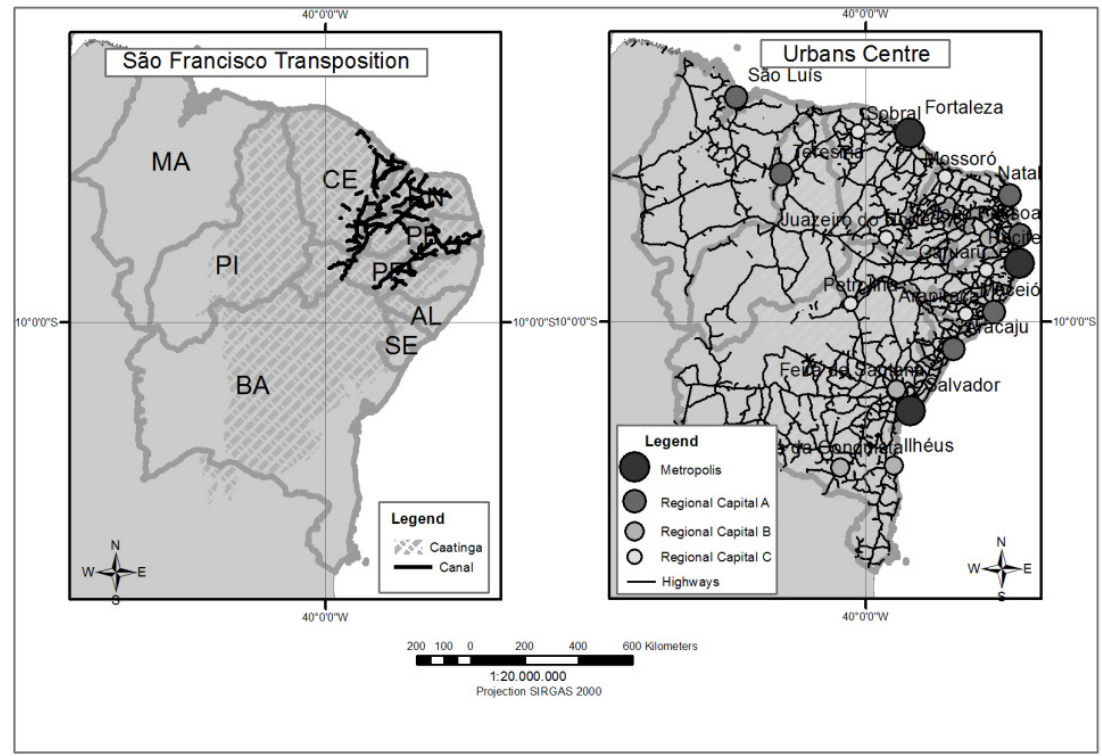

Figure 4: Most important urban centers and future canals of São Francisco transposition project. 


\subsection{Transmission lines}

By the historical exploitation of hydropower energy in Brazil, the arid region has been lacking transmission lines, as in some parts of the region there are no hydropower plans. The important hydropower plans are in São Francisco River and South of Piauí, a plan called Boa Esperança, which means Good hope [11].

So, the regions that are not crossed by the transmission lines to distribute this energy are historically lacked of lines [12]. As it is a region with low population, this did not come out as a problem so far. But if we intend to use solar energy as a significant part of Brazil's energy matrix, it will be necessary to build a major transmission line in some parts of the arid region.

This is the reason why Brazil has what is called "National System", which means that all energy produced feeds a unique system, and not a regional or local system. Thus, the greater the energy production, the greater lines are necessary. So, as the total amount of potential energy in the area is so high, it will be necessary to have an inter-state project to build a high voltage transmission line to serve this new resource or, at least, several substations.

As experience has shown, this can be a problem by the environmental point of view, due to great extensions of deforestation, visual pollution, interruption of ecological corridors and of course, the environmental and money cost of maintenance.

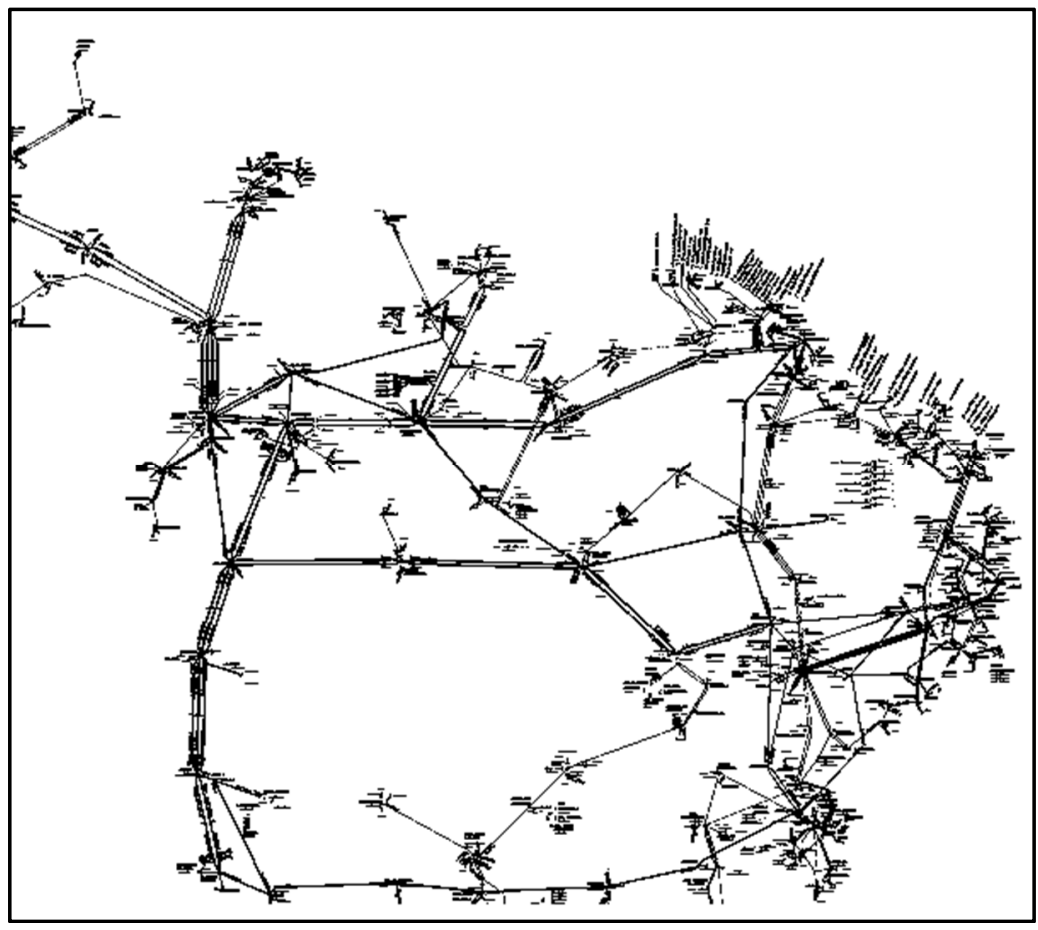

Figure 5: Transmission lines in Northeast Brazil. 


\subsection{Environmental license procedures}

Here we analyzed environmental law framework in the States involved and how they deal with current energy projects [13-19]. It is necessary to say that in Brazil when projects affect more than one State, the procedures for licenses emission are of federal competence. Although, when impacts affect a region inside the borders of a State, this State is the one that is in charge of license procedure.

However, they don't have the expertise to deal with these kinds of projects yet. None of them has a specific law or any prescriptive for these specific projects and they use directive and reference studies from eolic farms. The experience with emission of licenses for eolic energy projects shows how the state institutions can disorder licenses processes. Different demands, time terms and knowhow among the involved States have created disagreements in order to receive and have these projects.

After years of legal problems, which have repelled investors, there was a federal intervention with the creation of a specific law framework for eolic projects, involving a minimum term for environmental and social studies that support analyses for emission of licenses. This has put an end, or almost that, in this problem. It is not possible to ensure this as a conclusion, but eolic projects have increased after that. We believe that this must be done as soon as possible for solar farms.

\section{Conclusions}

As exploitation of solar energy is a reality and its price is interesting to investors, it is expected that the arid area of the Northeast Brazil could receive many of these projects. This situation brings concern by its social and environmental impacts.

These impacts are not just the direct ones, as deforestation of rural properties, pressure on wildlife, introduction of artificial structures in large areas and creation of large reflective areas, but indirect ones too, as land speculation, creation of access routes and local demand for water and energy as well as problems with conflicts between local and income populations.

One of these concerns is the existence of so few conservation units in this area. If there is a raising occupation of land in caatinga, the creation of new conservation units gets more and more difficult, due to the fact that Brazilian experiences in turning human occupied areas into environmental protected areas is a historical disaster, even resulting in tragic conflicts.

As the areas which need to be preserved or have any social or environmental interest are already mapped, it is necessary political effort to turn the establishment of more conservation units in caatinga biome real. It is not admissible that an episode like the parrot Ararinha-azul happens again, and there are many endemic and endangered plants and animals in caatinga biome which need the creation of these conservation units to be protected. 
Further, the places that have earned conservation units are seeing their economy rising with tourism and these cities also receive a good increase on the transfer of financial resources by the federal government.

About the urban centers, the ones that already exist inside the caatinga area can supply, at least in the beginning, facilities for the projects, with airport, routes and general supplies. It is expected that other cities will develop during the raising of the solar energy exploitation in the region. Raise of eolic projects in the coast has shown how small cities can have advantages with these projects.

It is necessary to remark that as the land is of an urban center, low is its money value, so, it is expected that some projects take place far from major urban centers, increasing the demand for infra-structure, which sometimes is made and constructed with public money by the government. It is important that the environmental institutions which analyses and authorize these projects do not permit excess of use of public money for private purposes.

The national and major projects for the region are supposed to provide water and easy, low cost access, as in an outflow. Thus, it is necessary that these projects get more attention from the federal government, because they have been postponed for years, and they represent a stranglehold on the positive impacts which are supposed to come along occupancy of areas in caatinga with solar farms.

The lack of transmission lines in the area can be a problem if not planned. Reality of other projects being held currently has shown that building these lines takes time and usually much more money than initially planned, so, this issue is a major concern and needs an accurate vigilance over it. As energy production in Brazil is not used in local area, but sent directly to the National System, if the energy production in the area increases, it is possible that a major transmission line might be necessary, or at least several well located substations.

Other major issue is on procedures to obtain environmental licenses. As there is no expertise about this at the state environmental institutions and knowledge of environmental impacts of solar farms are not very well known, it is extremely necessary that the federal environmental institution creates a law framework that can give directions for the state institutions, otherwise some States can be aggrieved and procedures will be very different among them. This fact can repel investors due to uncertainty in planning time and costs.

A quick overview on reference terms for studies to obtain licenses shows that States are using the studies for eolic farms as reference. Although there are some aspects that are alike, the impacts cannot be compared, as it affects particularly biological components that are not the same. Further, the environmental studies on this issue are very important to guide assuagement of negative impacts. Also, as there are so many priority areas for conservation due to lack of knowledge about them, these studies can contribute decisively to this knowledge.

Besides all these concerns, the occupation of part of the areas of the Brazilian "caatinga" for solar farms can be extremely positive for the development of the region, which is historically forgiven and has the worst rates of development of the country. So, there must be a deal in Brazil to develop the region in a sustainable way, which must include this model of energy generation. 


\section{References}

[1] C. F Freire. Conflitos ambientais e Áreas Prioritárias para Conservação em regiões de potencial para implantação de Usinas Solares Fotovoltaicas, Congresso Brasileiro de Planejamento Energético. Florianópolis, 2104.

[2] de Laborderie A., Puech C., Adra N., Blanc I., Beloin-Saint-Pierre D., Padey P., Payet J., Sie M., Jacquin Philippe. Environmental Impacts of Solar Thermal Systems with Life Cycle Assessment. World Renewable Energy Congress: Sweden; 2011.

[3] Tsoutsosa, T., FranteskakibNiki, Gekasb, Vassilis. Environmental Impacts from the Solar Energy Technologies. Energy Policy: 33. 2005; pp. 289296.

[4] Pereira, E. B; Martins, F. R.; Abreu, S. L.; Rüther, R. Atlas Brasileiro de Energia Solar. São José dos Campos, $1^{\circ}$ edição, 2006; 64 p.

[5] Ministério do Meio Ambiente (MMA). Website, Brasília, http://www.ministeriodomeioambiente.gov.br/biomas/caatinga

[6] Ministério do Meio Ambiente (MMA). Web site, Brasília, http://www.mma.gov.br/biodiversidade/biodiversidade-brasileira/

[7] Ministério do Meio Ambiente (MMA). Biodiversidade Brasileira: Avaliação e Identificação de Áreas e Ações Prioritárias para Conservação, Utilização Sustentável e Repartição de Benefícios da Biodiversidade Brasileira (Press), Brasília, 2002.

[8] Ministério do Meio Ambiente (MMA). Áreas Prioritárias para a Conservação, Utilização Sustentável e Repartição de Benefícios da Biodiversidade Brasileira (Press), Brasília, 2002.

[9] Instituto de Pesquisa Econômica Aplicada. IPEA, http://www.ipea.gov.br /portal/index

[10] Ministério da Integração Nacional, http://www.integracao.gov.br/

[11] Ministério das Minas e Energia (MME). Boletim Mensal do Sistema Elétrico Brasileiro (Press), Brasília, 2014.

[12] Ministério das Minas e Energia (MME). Operador do Sistema Elétrico (ONS) Web site. Transmission lines, maps and planning's, Brasília 2015, http://www.ons.org.br/home/

[13] Secretaria de Estado do Meio Ambiente e Desenvolvimento Sustentável de Minas Gerais, www.meioambiente.mg.gov.br/

[14] Secretaria do Meio Ambiente do estado da Bahia - SMA, www.meioambiente.ba.gov.br/

[15] Secretaria Estadual de Meio Ambiente e Sustentabilidade de Pernambuco, www.pe.gov.br/

[16] Superintendência de Administração do Meio Ambiente da Paraíba SUDEMA, www.sudema.pb.gov.br/

[17] Instituto de Desenvolvimento Sustentável do Rio Grande do Norte, www.idema.rn.gov.br/

[18] Secretaria do Meio Ambiente do estado do Ceará, www.semace.ce.gov.br/

[19] Secretaria do Meio Ambiente e dos Recursos Hídricos do Piauí, www.semar.pi.gov.br/index.php 